\section{KẾT LUÂ̂N}

Thông tin chung về đối tượng nghiên cứu: Nghiên cứu thực hiện sàng lọc 1524 trẻ tại 3 xã của huyện Quỳnh Phụ tỉnh Thái Bình. Tỷ lệ bao phủ của sàng loc đat $96,3 \%$.

Tỷ lệ trẻ khuyết tật: Tỷ lệ trẻ khuyết tật trong nghiên cứu là $1,12 \%$ trong đó tỷ lệ nam/nữ là $1,4 / 1$. Trong phân loại khuyết tật, tỳ lệ trẻ khó khăn về học chiếm tỷ lệ cao nhất là $35,3 \%$ sau đó là trẻ khó khăn về nhìn $(23,5 \%)$, trẻ khó khăn về nghe - nói $(17,6 \%)$, vận động $(11,7 \%)$. Tỷ lệ trẻ có hành vi xa la bằng với tỷ lệ trẻ có các khuyết tật khác $(5,9 \%)$ và không ghi nhận trẻ động kinh.

\section{KHUYẾN NGH!}

Nên mở rộng phạm vi sàng lọc trẻ khuyết tật để nhằm phát hiện sớm, can thiệp sớm tạo cơ hội cho trẻ được đến trường và hòa nhập xã hội. Có thể triển khai trên các địa bàn, khu vực khác để tạo điều kiện cho trẻ được can thiệp sớm khuyết tật, cải thiện chức năng.

\section{TÀI LIẸU THAM KHẢO}

1. Sanjeeva GN (2016), Early detection of disabilities in Children, Indira Gandhi Institute of Child Health, Bangalore .

2. Tổng cục thống kê (2019). Kết quả tổng điều tra dân số và nhà ở năm 2019. Hà Nội.

3. Nguyễn Thị Minh Thủy, Đố Chí Hùng, Nguyễn Thi Thu Hằng và cộng sự (2017). Thực trạng khuyết tật ở trẻ dưới 6 tuổi tại Hà Nội năm 2014 2015. Tạp chí $Y$ học dự phòng, 27, 117 - 120.

4. Trân Vằn Vương (2015). Đánh giá thực trang khuyết tật và các hoạt động phục hồi chức nẳng dưa vào công đồng chio trè khuyểt tâ dưới 6 tuổi ở huyện Hạ Hòa - Phú Thọ năm 2014, Luận văn Bác sĩ chuyên khoa II, Trường Đai hoc Y Yà Nội.

5. Phạm Bích Phương (2017). Thực trang khuyết tật ở trẻ từ $0-6$ tuôi và kiến thức thái độ của người chăm sóc về phát hiện sớm khuyết tất ở trẻ tại huyện Quỳnh Phụ tỉnh Thái Bình, Luận văn Thạc sĩ Y tể công cộng, Trường Đại học Y Y Dược Thái Bình.

6. Xue Zhong, Xiaoli Zhao, Zhuoya Liu at el (2020). Childhood disability and its associated perinatal characteristics in Bao'An distric of Shenzhen, China. BMC Public Health, 20(1), 15-40.

\title{
MộT SỐ YẾU TỐ LIÊN QUAN ĐẾN RỐI LOAN TRẦM CẢM Ở BÊ̂NH NHÂN GOUT MẠN TÍNH
}

\author{
Nguyễn Đình Hoàng ${ }^{\mathrm{a}}$, Nguyễn Doãn Phươnga ${ }^{\mathrm{a}, \mathrm{b}}$, \\ Nguyễn Văn Tuấn ${ }^{\mathrm{a}, \mathrm{b}}$, Lê Công Thiện ${ }^{\mathrm{a}, \mathrm{b}}$
}

\section{TÓM TẮT}

Đặt vấn đề: Gout là bệnh khớp thường gặp ở Việt Nam cũng như nhiêu nước trên thế giới. Ơ đợt cẩp của bệnh, bệnh nhân thường phải chịu nhiều đau đớn, hạn chế vận động, ảnh hưởng đến giấc ngủ, công việc, các mối quan hệ gây ảnh hưởng nhiều đến cảm xúc của nhóm đối tượng này. Việc đánh giá các yếu tố liên quan có giá trị dự đoán khả năng trầm cảm ở nhóm đối tượng này từ đó có những can thiệp sớm cho những đối tượng nguy cơ cao. Mục tiêu: Đánh giá một số yếu tố liền quan đến rối loạn trầm cảm ở bệnh nhân Gout mạn tính. Đối tượng và phương pháp nghiên cứu: Nghiên cứu mô tả cắt ngang trên 129 bênh nhân gout mạn tính, được chẩn đoán điều trị nội trú tại khoa Cơ xương khớp Bệnh viện Bạch Mai từ tháng $11 / 2020$ đên tháng $05 / 2021$, có sử dụng thang điểm đánh giá HAM-D và thăm khám lâm sàng. Kết quả: Có mối liên quan giữa tỷ lệ trầm cảm và các

\footnotetext{
aĐại học Y Hà Nội

bViện Sức Khỏe Tâm Thần-Bệnh Viện Bạch Mai

Chịu trách nhiệm chính: Nguyễn Đình Hoàng

Email: Dinhhoang12121995@gmail.com

Ngày nhận bài: 12.7.2021

Ngày phản biện khoa học: 6.9.2021

Ngày duyệt bài: 14.9.2021
}

yếu tố về khả năng lao động sinh hoạt, số lần vào viện, mức độ đau, rối loạn giấc ngủ, rối loạn lo âu kèm theo với kết quả có ý nghĩa thống kê $(\dot{p}<0,05)$. Không tìm thấy mối liên quan giữa tuổi, giới tính, trình độ hoc vấn, tình trang kinh tế, tình trang hôn nhân hay thời gian mắc bệnh với trầm cảm. Kết luận: Cần có biện pháp can thiệp sớm và phù hợp cho các đối tượng có nguy cơ trầm cảm cao.

Tư khóa: trầm cảm, gout.

\section{SUMMARY \\ FACTORS RELATED TO DEPRESSIVE} DISORDER IN CHRONIC GOUT PATIENTS

Background: Gout is a common joint disease in Vietnam as well as many countries around the world. In the acute phase of the disease, patients often have to suffer a lot of pain, limit movement, affect sleep, work, and relationships, which greatly affect the emotions of this group of subjects. The assessment of relevant factors is valuable in predicting the likelihood of depression in this group of subjects, thereby making early interventions for high-risk subjects. Objectives: To evaluate some factors related to depressive disorder in patients with chronic gout. Subjects and methods: A cross-sectional descriptive study on 129 chronic gout patients, diagnosed as inpatient treatment at the Department of Musculoskeletal Medicine, Bach Mai Hospital from 
November 2020 to May 2021, using HAM-D scale and clinical examination. Results: There was a relationship between the rate of depression and factors such as working ability, number of hospital admissions, pain level, sleep disturbance, anxiety disorder with significant results. statistics $(p<0.05)$. No association was found between age, sex, education level, economic status, marital status or duration of illness with depression. Conclusion: Early and appropriate interventions are needed for subjects at high risk of depression.

Keywords: depression, gout.

\section{I. Đă̆T VẤN ĐỀ}

Gout là bệnh khớp thường gặp ở Việt Nam cũng như nhiều nước trên thế giới. Bệnh thường gặp ở các nước phát triển, chiếm khoảng 0,020,2\% dân số thế giới, với 95\% là nam giới, trung niên (30-40 tuổi), nữ giới thường gặp ở tuổi 6070 [1]. Bệnh gây đau nghiêm trọng, hạn chế khả năng vận động, ảnh hưởng lớn đến kinh tế, tâm lí, chất lượng cuộc sống người bệnh.

Rối loạn trâm cảm đã và đang dân trở thành một bệnh lý phổ biến tại Việt Nam cũng như trên cả thế giới. Theo Tổ chức Y tế Thế giới, các rối loạn trầm cảm là nguyên nhân hàng thứ ba của gánh nặng bệnh tật trên toàn thế giới trong năm 2004 và sẽ chuyển sang vị trí đâu tiên vào năm 2030[2]. Trâm cảm là một rối loạn tâm thân thường gặp ở những bệnh nhân Gout mạn. Trâm cảm làm làm tăng đáng kể gánh nặng bệnh tật ở những bệnh nhân mắc bệnh mạn tính [3]. Theo nghiên cứu của Song Lin và cộng sự (2018), bệnh nhân Gout có tỷ lệ mắc trâm cảm cao hơn $19 \%$ so với người khổng mắc bệnh [4]. Các nghiên cứu của Ting Fu (2018) [5], Zhou (2018) [6], Pazcoguin (2018) [7] cho thấy trâm cảm ở bệnh nhân gout liên quan tới một số yếu tố như số đợt cấp, mức độ đau, thời gian mắc bệnh, khả năng lao động, chức năng.... Việc tìm hiểu các yếu tố liên quan đến trâm cảm ở bệnh nhân gout mạn tính là rất cân thiết giúp dự báo, tiên lượng và hỗ trợ điều trị nhưng chưa được nghiên cứu tại Việt Nam. Vì vậy chúng tôi tiến hành nghiên cứu với mục tiêu: Phân tích một số yêu tố liên quan đến rối loạn trầm cảm ở bệnh nhân gout mạn tính.

\section{II. ĐỐI TƯợNG VÀ PHƯƠNG PHÁP NGHIÊN CỨU}

2.1 Đối tượng nghiên cứu: 129 bệnh nhân được chẩn đoán gout mạn tính được điều trị nội trú tại khoa Cơ xương khớp Bệnh viện Bạch Mai từ tháng 11/2020 đến tháng 05/2021

Tiêu chuẩn lựa chọn: - Bệnh nhân gout mạn tính đã được các bác sỹ chuyên khoa Cơ xương khớp Bệnh viện Bạch Mai chẩn đoán theo tiêu chuẩn của Bennett và Wood 1968.
- Có sự đồng ý tham gia của bệnh nhân và người nhà.

\section{Tiêu chuẩn loại trừ:}

- Bệnh nhân bỏ cuộc hoặc không hợp tác trả lời được hết bô câu hỏi.

- Bệnh nhân có tình trạng trâm cảm từ trước khi khám, phát hiện gout hay tiên sử chẩn đoán, điều trị rối loạn trầm cảm trước đó.

\subsection{Phương pháp nghiên cứu:}

- Nghiên cứu mô tả cắt ngang với cách chọn mẫu thuận tiện. Từ mục tiểu nghiên cứu xây dựng bệnh án nghiên cứu phù hợp, tiến hành phỏng vấn và khám tâm thân bệnh nhân kèm bộ câu hỏi HAM-D

- Nhập và xử lý số liệu bằng phân mềm SPSS 25.0. Tiến hành phân tích thống kê mô tả, tính tân suất của các biểu hiện, so sánh các tỉ lệ, tính tương quan.

2.3 Đạo đức nghiên cứu: Nghiên cứu không can thiệp, mục đích giúp đánh giá đây đủ và điều trị hiệu quá hơn cho bệnh nhân và chỉ tiến hành khi có sự đồng ý của bệnh nhân và người nhà. Nghiên cứu đã được sự đồng ý của trường Đại học Y Hà Nội và cơ sở nghiên cứu.

\section{KẾT QUẢ NGHIÊN CứU}

\section{1. Đăc điểm chung của nhóm đôi tượng} nghiên cứu

Bảng 3.1: Đăc điểm chung của nhóm đôî tượng nghiên cứu

\begin{tabular}{|c|c|c|c|}
\hline & ạc điểm & $\begin{array}{c}\text { Tổng } \\
\text { số }\end{array}$ & $\begin{array}{l}\text { Tỷ lệ } \\
(\%))^{2}\end{array}$ \\
\hline \multirow{5}{*}{ Tuổi } & Dưới 40 tuối & 6 & 4,7 \\
\hline & 40-49 tuối & 19 & 14,7 \\
\hline & 50-59 tuổi & 39 & 30,2 \\
\hline & 60-69 tuối & 46 & 35,7 \\
\hline & $>=70$ tuổi & 19 & 14,7 \\
\hline \multirow{2}{*}{ Giới } & Nam & 127 & 98,4 \\
\hline & Nữ & 2 & 1,6 \\
\hline \multirow[b]{2}{*}{ Dân tộc } & Kinh & 112 & 86,8 \\
\hline & Khác & 17 & 13,2 \\
\hline \multirow{3}{*}{$\begin{array}{l}\text { Khu vực } \\
\text { sống }\end{array}$} & Nông thôn & 93 & 72,1 \\
\hline & Thành thị & 25 & 19,4 \\
\hline & Miênn núi & 11 & 8,5 \\
\hline \multirow{7}{*}{$\begin{array}{l}\text { Nghêe } \\
\text { nghiệp }\end{array}$} & Công nhân & 2 & 1,6 \\
\hline & Kinh doanh & 6 & 4,6 \\
\hline & Thất nghiệp & 2 & 1,6 \\
\hline & Nông dân & 44 & 34,1 \\
\hline & Cán bộ & 10 & 7,8 \\
\hline & Nghì hưu & 22 & 17,1 \\
\hline & Khác & 43 & 33,2 \\
\hline \multirow{3}{*}{$\begin{array}{l}\text { Trình độ } \\
\text { học vấn }\end{array}$} & Mù chữ & 1 & $0,8 \%$ \\
\hline & Tiểu học & 18 & $14,0 \%$ \\
\hline & Trung học cơ sơ & 54 & $41,8 \%$ \\
\hline
\end{tabular}




\begin{tabular}{|c|c|c|c|}
\hline \multirow{4}{*}{$\begin{array}{c}\text { Nghề } \\
\text { nghiệp }\end{array}$} & Trung học phố thông & 36 & $27,9 \%$ \\
\cline { 2 - 4 } & $\begin{array}{c}\text { Trung cấp-cao đằng- } \\
\text { Đại học/ sau đại học }\end{array}$ & 20 & $15,5 \%$ \\
\cline { 2 - 4 } & Thất nghiệp, nội trợ & 5 & 2,6 \\
\cline { 2 - 4 } & Cán bộ viên chức & 68 & 36,0 \\
\cline { 2 - 4 } & Công nhân & 39 & 20,6 \\
\cline { 2 - 4 } & Nông dân & 12 & 6,3 \\
\cline { 2 - 4 } & Nghề tự do & 50 & 26,6 \\
\hline \multirow{3}{*}{$\begin{array}{c}\text { Tình trạng } \\
\text { hôn nhân }\end{array}$} & Khác & 15 & 7,9 \\
\cline { 2 - 4 } & Khưa kết hôn & 3 & 2,3 \\
\hline \multirow{2}{*}{$\begin{array}{c}\text { Tình trạng hôn } \\
\text { kinh tế }\end{array}$} & Góa & 124 & 96,1 \\
\cline { 2 - 4 } & Khó khăn & 2 & 1,6 \\
\cline { 2 - 4 } & Trung bình & 117 & 9,2 \\
\hline \multirow{2}{*}{ Khá giả } & 4 & 3,1 \\
\hline
\end{tabular}

Nhận xét: - Tuối: Chủ yếu là bệnh nhân trên 40 tuổi chiếm tỷ lệ 95,3\%, trong đó nhóm tuổi 5059 chiếm 30,2\%, nhóm tuổi 60-69 chiếm 35,7\%, ít nhất là nhóm tuổi dưới 40 chỉ chiếm 4,7\%.

- Tuổi trung bình của nhóm nghiên cứu là $58,88 \pm 10,96$, thấp nhất là 25 tuổi, cao nhất là 88 tuổi.

- Giới: Đa số bệnh nhân trong nghiên cứu là nam giới chiếm 98,4\%

- Dân tộc: Phân lớn đối tượng tham gia nghiên cứu là nhóm đối tượng dân tộc Kinh chiếm $86,8 \%$.

- Khu vực sống: Tỷ lệ bệnh nhân ở khu vực nông thôn cao nhất $(72,1 \%)$, thành thị chiếm $19,4 \%$, còn lại là khu vực miền núi $(8,5 \%)$

- Nghề nghiệp: Đ̇a số bệnh nhân trong nhóm nghiên cứu là nông dân (chiếm 34,1\%). Sau đó là nhóm nghỉ hưu (17,1\%). Nhóm công nhân và thất nghiệp ít nhất chiếm tỷ lệ 1,6\%.

- Trình độ học vấn : Đa số nhóm tham giam gia nghiên cứu có trình độ học hết trung học cơ sở (THCS) chiếm 41,9\%, sau đó là nhóm Trung học phổ thông (THPT) chiếm tỷ lệ 27,9\%, 15,5\% có trình độ trung cấp- cao đẳng- đại học/ sau đại học và có 1 bệnh nhân không biết chữ chiếm tỷ lệ $0,8 \%$.

2. Đặc điểm lâm sàng bệnh gout mạn tính của nhóm bênh nhân nghiên cứu.

Bảng 3.2. Đặc điểm lâm sàng bệnh Gout man tính

3. Một số yếu ố liên quan với rối loạn trâm cảm ở bệnh nhân gout mạn tính.

Bảng 3.3: Một số yêu tố liên quan với rối loạn trâm cảm:

\begin{tabular}{|c|c|c|c|c|c|c|}
\hline \multirow{2}{*}{ Yếu tố liên quan } & \multicolumn{2}{|c|}{ Không trâm cảm } & \multicolumn{2}{|c|}{ Trâm cảm } & \multirow{2}{*}{ OR } & \multirow{2}{*}{$\mathbf{p}$} \\
\cline { 2 - 5 } & $\mathbf{n}$ & $\mathbf{\%}$ & $\mathbf{n}$ & $\mathbf{\%}$ & & \\
\hline Giới $($ nam) & 60 & 72,3 & 23 & 27,7 & 0,309 & $0,424^{* *}$ \\
\hline Tuối $\geq 60$ & 50 & 76,9 & 15 & 23,1 & 0,900 & $0,798^{*}$ \\
\hline Trình độ học vấn & 84 & 76,4 & 26 & 23,6 & 0,867 & $0,777^{* *}$ \\
\hline Tình trạng kinh tế & 4 & 50 & 4 & 50 & 3,481 & $0,094^{* *}$ \\
\hline
\end{tabular}

\begin{tabular}{|c|c|}
\hline Đặc điếm về lâm sàng & $\overline{\mathbf{X}} \pm$ SD \\
\hline Số khớp sưng & $4,41 \pm 3,03$ \\
\hline Số khớp đau & $4,44 \pm 3,07$ \\
\hline VAS & $5,8 \pm 1,25$ \\
\hline
\end{tabular}

Nhânn xét: Số khớp sưng, số khớp đau trung bình theo thứ tự là 4,41 $\pm 3,03 ; 4,44 \pm 3,07$ (khớp). Điểm VAS trung bình là $5,8 \pm 1,25$ (Thấp nhất là 0 điểm, cao nhất là 10 điểm).

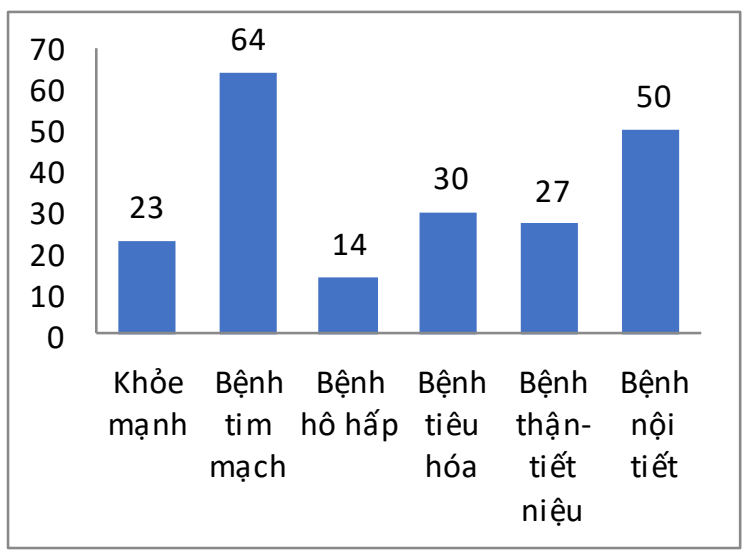

Biểu đồ 1: Tiền sử các bệnh đã mắc

Nhânn xét: Trong tổng số 129 BN nghiên cứu thì số người có tiền sử khỏe mạnh là 23 người (chiếm 17,8\%). Trong số 106 người có tiên sử mắc bệnh thì tỉ lệ các bệnh lí tim mạch chiếm tỉ lệ cao nhất $(49,6 \%)$, tiếp theo là đến tỉ lệ mắc bệnh nội tiết $(38,8 \%)$, tiêu hóa (23,3\%). Trong đó các bệnh lí thường gặp nhất là tăng huyết áp $(47,3 \%)$ và đái tháo đường $(27,9 \%)$.

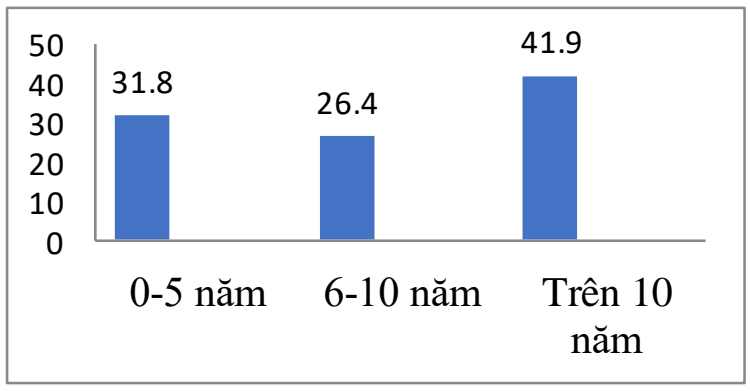

Biểu đồ 3.2 Biểu đồ về thời gian mắc bênh

Nhận xét: Tỷ lệ bệnh nhân mắc bệnh trên 10 năm có tỷ lệ cao nhất 41,9\% 
VIETNAM MEDICAL JOURNAL N¹ - OCTOBER - 2021

\begin{tabular}{|c|c|c|c|c|c|c|}
\hline Tình trạng hôn nhân & 93 & 75,0 & 31 & 25,0 & 0,75 & $0,336^{* *}$ \\
\hline Khả năng lao động sinh hoạt & 39 & 60 & 26 & 40 & 7,867 & $0,000^{* *}$ \\
\hline Thời gian mắc bệnh ( $>10$ năm) & 39 & 72,2 & 15 & 27,8 & 1,418 & $0,398^{*}$ \\
\hline Số lần nhập viện ( $\geq 3$ lần) & 26 & 59,1 & 18 & 40,9 & 3,834 & $0,001^{*}$ \\
\hline Mức độ đau theo VAS (đau nặng) & 6 & 26,1 & 17 & 73,9 & 18,62 & $0,000^{*}$ \\
\hline Rối loạn giấc ngủ & 60 & 65,9 & 31 & 34,1 & 1,52 & $0,000^{*}$ \\
\hline Rối loạn lo âu kèm theo & 9 & 25,7 & 26 & 74,3 & 51,42 & $0,000^{*}$ \\
\hline
\end{tabular}

**: Sử dung Fisher's exact test đế đánh giá mối liên quan, với ý nghĩa thống kê $\mathrm{p}<0,05$

* Sử dụng test $X^{2}$ (Khi bình phương) đánh giá mối liên quan, với ý nghĩa thống kê $p<0,05$

Nhận xét: - Tỷ lệ trầm cảm ở bệnh nhân nam và̀ nữ khác nhau không có ý nghĩa thống kê $(p=0,424)$

- Bệnh nhân với các nhóm tuổi, trình độ học vấn, tình trạng hôn nhân, tình trạng kinh tế có tỷ lệ trầm cảm khác nhau không có ý nghĩa thống kê với $p<0,05$

- Những bệnh nhân có khả năng lao động sinh hoạt kém do bệnh gout mạn có tỷ lệ trầm cảm cao có ý nghĩa thống kê với $p=0,000, O R=7,867$

- Bệnh nhân có thời gian mắc bệnh trên 10 năm có tỷ lệ trầm cảm cao hơn nhóm mắc bệnh dưới 10 năm không có ý nghĩa thống kê với $p=0,398$.

- Bệnh nhân có 3 lần trở lên nhập viện vì đợt cấp trong năm có nguy cơ mắc trầm cảm cao hơn 3,834 lần, có ý nghĩa thống kê với $p=0,001$.

- Bệnh nhân có mức độ đau nặng do gout( theo thang điểm VAS) có tỷ lệ trầm cảm cao hơn có ý nghĩa thống kê với $p=0,000, O R=18,62$

- Bệnh nhân có rối loạn giấc ngủ, rối loạn lo âu kèm theo có tỷ lệ trầm cảm cao hơn, có ý nghĩa thống kê với $p<0,05$.

\section{BÀN LUÂ̂N}

Chúng tôi đã thực hiên khảo sát về các yếu tố nhân khẩu học gồm tuổi, giới, dân tộc, nghề nghiệp và khu vực sống của nhóm đối tượng nghiển cứu. Trong 129 bệnh nhân nghiên cứu, chủ yếu là bệnh nhân nam chiếm $98,4 \%$, độ tuối trung bình là $58,88 \pm 10,96$. Số bệnh nhân được xác định có rối loạn trầm cảm là 31 bệnh nhẩn chiếm 24,03\%.

Bảng 3.3 chỉ ra mối tương quan giữa tỷ lệ trầm cảm và một số yếu tố liên quan. Trong đó những bệnh nhân có khả năng hoạt động sinh hoạt kém, số lần nhập viện nhiều, đau nhiều, có rối loạn giấc ngủ, rối loạn lo âu kèm theo có tỷ lệ trầm cảm cao có ý nghĩa thống kê.

Một số nghiên cứu trên thế giới cũng đưa ra kết luận tương tự, cụ thể trong nghiên cứu của Ting Fu (2018) [5] cho thấy có sự liên quan giữa trầm cảm và năng lực chức năng của người bệnh giá qua thang điểm HAQ-DI và mức độ đau (theo thang điểm VAS) có sự khác biệt có ý

nghĩa thống kê với $p<0,05$. Zhou và cộng sự (2018) nghiên cứu 186 BN gout ở Đài Loan cho thây có mối liên quan giữa số đợt cấp bùng phát gout với tỷ lệ trầm cảm với $p<0,001[6]$. Pazcoguin và cộng sự (2018) nghiên cứu trầm cảm và các đặc điểm liên quan ở $\mathrm{BN}$ gout ở Philipin trên 75 BN cũng cho thấy sự liên quan giữa trầm cảm và mức độ đau, số đợt cấp trong 1 năm với $p<0,05$ [7]. Tương tự Pior và cộng sự (2016) nghiên cứu đặc điểm của gout với trầm cảm trên 1189 Bn cho kết quả số đợt cấp trên 3 lần 1 năm bệnh nhân gout có nguy cơ trầm cảm tăng gấp 3,25 lần với $p<0,05$ [8].

Trong nghiên cứu của chúng tôi không tìm thấy mối liên quan giữa các yếu tố giới tính, tuổi, trình độ học vấn, tình trạng kinh tế, tình trạng hôn nhân hay thời gian mắc bệnh với tỷ lệ trầm cảm với $p>0,05$. Kết quả này vừa có sự tương đồng vừa có sự khác biệt với các nghiên cứu khác trên thế giới [5], [7],[9]. Điều này gợi ý cần các nghiên cứu sâu hơn nữa để tìm hiểu các yếu tố liên quan đến rối loạn trầm cảm ở bệnh nhân gout mạn tính.

\section{KẾT LUÂ̂N}

- Có mối liên quan giữa tỷ lệ trầm cảm ở bệnh nhân gout mạn tính và các yếu tố về khả nằng lao động sinh hoạt, số lần vào viện, mức độ đau, rối loạn giấc ngủ, rối loạn lo âu kèm theo.

- Không thấy có mối liên quan giữa các yếu tố khác như tuổi, giới tính, trình độ học vấn, tình trạng kinh tế, tình trạng hôn nhân hay thời gian mắc bệnh đến trầm cảm ở bệnh nhân gout mạn tính.

\section{TÀI LIÊU THAM KHẢO}

1. Ngố Quý Châu (2012), Bệnh học nội khoa tập 2, Nhà xuất bản y học, Hà Nội.

2. Jp L. và M B. (2011). The increasing burden of depression. Neuropsychiatric disease and treatment, 7(Suppl 1).

3. Simon G.E. (2001). Treating depression in patients with chronic disease. West J Med, 175(5), 292-293.

4. Lin S., Żhang H., và Ma A. (2018). Association of gout and depression: A systematic review and meta-analysis. International Journal of Geriatric Psychiatry, 33(3), 441-448. 
5. Fu T., Cao H., Yin R. và cộng sự. (2018). Depression and anxiety correlate with diseaserelated characteristics and quality of life in Chinese patients with gout: a case-control study. Psychol Health Med, 23(4), 400-410.

6. Lower vitamin D levels are associated with depression in patients with gout. <https://www.ncbi.nlm.nih.gov/pmc/articles/PMC6 338117/>, accessed: 28/08/2021.

7. Pazcoguín J.M., Vargas M.A.S., và Manlapaz D. (2018). AB1457-HPR Aggression, depression level and gout-related characteristics among filipinos diagnosed with gouty arthritis: a crosssectional, multi-centre study. 1860.2-1860.

8. Prior J.A., Mallen C.D., Chandratre P. và cộng sư. (2016). Gout characteristics associate with depression, but not anxiety, in primary care: Baseline findings from a prospective cohort study. Joint Bone Spine, 83(5), 553-558.

9. Changchien T.-C., Yen Y.-C., Lin C.-L. và cộng sư. (2015). High Risk of Depressive Disorders in Patients With Gout. Medicine (Baltimore), 94(52).

\title{
DẤU ẤN HBcrAg HUYẾT THANH TRONG DIỄN BIẾN TỰ NHIÊN Ở BỆNH NHÂN VIẾM GAN VI RÚT B MẠN TẠI BỆNH VIỆN BACCH MAI
}

\author{
Nguyễn Vũ Hồng Vân*, Lê Thị Huyền*, Lê Thị Ngân**, \\ Trương Thái Phương**, Nguyễn Văn Dũng***
}

\section{TÓM TẮT}

Mục tiêu: Đánh giá nồng độ HBcrAg huyết thanh và tướng quan với các dấu ấn vi rút viêm gan $B$ trong các giai đoạn tự nhiên của viêm gan vi rút $B$ mạn. Phương pháp nghiên cứu: Nghiên cứu mô tả cắt ngang có phân tích tiến cứu 127 bệnh nhân viêm gan vi rút $B$ man chưa điều tri được theo dõi tai Trung tâm Bệnh Nhiệt đới Bệnh viện Bạch Mai. Kết quả: Nông đổ HBcrAg ở các giai đoạn nhiễm trùng man HBeAg dương tính (EPCI), viêm gan mạn $\mathrm{HBeAg}$ dương tính $(E P C H)$, nhiếm trùng mạn $\mathrm{HBeAg}$ âm tính (ENCI), viêm gan man $\mathrm{HBeAg}$ âm tính $(\mathrm{ENCH})$, thanh thái $\mathrm{HBsAg}$ (SC) lần lượt là $6,84 \pm 0,45 \mathrm{logU} / \mathrm{ml} ; 6,7 \pm 0,59$ $\log \mathrm{U} / \mathrm{ml} ; 3,15 \pm 0,86 \mathrm{log} / \mathrm{ml} ; 4,75 \pm 1,57 \quad \log \mathrm{U} / \mathrm{ml} ;$ $2,43 \pm 0,44 \log \mathrm{J} / \mathrm{ml}$. HBcrAg tương quan với HBV-DNA $(r=0,785 ; p=0,000)$, mạnh nhất ở giai đoạn EPCI $(r=0,988)$. HBcrAg tương quan với HBsAg ở mức độ trung bình $(r=0,653 ; p=0,00)$; tương quan với $A S T$, ALT trong giai đoạn ENCH với hệ số lần lượt $r=0,527$, $p=0,001$ và $r=0,335, p=0,049$. Ngoài ra, HBcrAg có thể phát hiện tới $75 \%$ trong nhóm thanh thải HBsAg. Kết luận: Nồng độ HB̉BcrAg phân bố khác nhau trong suốt các giai đoạn diễn biến tự nhiên của viêm gan vi rút B mạn. Nồng độ HBcrAg có mối tương quan mạnh với tải lượng HBV-DNA trong tất cả các giai đoạn, có thể phản ánh sự nhân lên của vi rút.

Từ khóa: Kháng nguyên liên quan đến lõi của vi rút viêm gan $B$ (HBcrAg); viêm gan vi rút $B$ mạn; diễn biến tự nhiên.

\section{SUMMARY \\ HEPATITIS B CORE-RELATED ANTIGEN IN THE NATURAL HISTORY OF CHRONIC}

*Truyền nhiễm và các bệnh Nhiệt đới trường ĐHY Hà Nội **Bệnh viện Bach Mai

***Trung tâm bệnh Nhiệt đới Bệnh viên Bạch Mai

Chịu trách nhiệm chính: Nguyễn Vũ Hồng Vân

Email: hongvan2181995@gmail.com

Ngày nhận bài: 9.7.2021

Ngày phản biên khoa học: 6.9.2021

Ngày duyệt bài: 13.9.2021
HEPATITIS B AT BACH MAI HOPITAL

Objectives: analyzing serum $\mathrm{HBcrAg}$ levels and correlation of $\mathrm{HBcrAg}$ with markers of hepatitis $B$ virus in the natural of chronic hepatitis B. Methods: Crosssectional descriptive prospective with analysis study of 127 treatment-naive chronic hepatitis B patients monitored at the Tropical Diseases Center of Bach Mai hospital. Results: HBcrAg levels in the groups of Hepatitis B e antigen (HBeAg)-positive chronic infection (EPCI), HBeAg-positive chronic hepatitis $(\mathrm{EPCH})$, HBeAg-negative chronic infection (ENCI), HBeAg-negative chronic hepatitis (ENCH), Hepatitis B $\mathrm{s}$ antigen (HBsAg) clearance (SC) were $6.84 \pm 0.45$ $\log \mathrm{U} / \mathrm{ml} ; \quad 6.7 \pm 0.59 \operatorname{logU} / \mathrm{ml} ; 3.15 \pm 0.86 \log \mathrm{U} / \mathrm{ml}$; $4.75 \pm 1.57 \mathrm{logU} / \mathrm{ml} ; 2.43 \pm 0.44 \mathrm{logU} / \mathrm{ml}$, respectively. The overall correlation of HBcrAg with HBV-DNA was strong in this study $(r=0.785 ; p=0.000)$, the strongest in the EPCI group $(r=0.988)$. The correlation of HBcrAg with HBsAg was moderate $(r=0.653 ; p=0.00)$. Correlation of HBcrAg with AST, ALT in the ENCH group were $r=0.527, p=0.001$ and $r=0.335, p=0.049$, respectively. In addition, $\mathrm{HBcrAg}$ was detectable up to $75 \%$ in the SC group. Conclusion: Serum HBcrAg levels are distributed differently groups in the natural of chronic hepatitis B. The correlation HBcrAg with HBV-DNA was strong in all groups, HBcrAg may as valuable marker for virus replication.

Keywords: Hepatitis B core-related antigen (HBcrAg); chronic hepatitis B virus; in the natural history.

\section{I. ĐẶT VẤN ĐỀ}

Nhiễm vi rút viêm gan $B$ (Hepatitis $B$ virus: HBV) mạn là mối đe dọa sức khỏe toàn câu nghiêm trọng. Theo báo cáo năm 2017 của Tổ chức Y tế thế giới, ước tính năm 2015 toàn cầu có khoảng 257 triệu người nhiễm HBV mạn và 884.400 người tử vong, trong đó có $30 \%$ tử vong do xơ gan và $40 \%$ tử vong do ung thư biểu mô tế bào gan ${ }^{1}$. Mặc dù hiện nay có nhiều loại thuốc điều trị viêm gan $B$ nhưng lại không thể 